\title{
A rare triple threat: Rat bite fever, endocarditis of ventricular septal defect patch, and multivalve endocarditis with sinus of Valsalva fistula
}

\author{
Meena Nathan, MD, MPH
}

\author{
From the Department of Cardiac Surgery, Boston Children's Hospital, Harvard Medical School, Boston, Mass. \\ Disclosures: Author has nothing to disclose with regard to commercial support. \\ Received for publication Oct 31, 2016; accepted for publication Nov 1, 2016; available ahead of print Dec 9, 2016 \\ Address for reprints: Meena Nathan, MD, MPH, Department of Cardiac Surgery, Boston Children's Hospital, 300, \\ Longwood Ave, Boston, MA 02115 (E-mail: meena.nathan@ cardio.chboston.org). \\ J Thorac Cardiovasc Surg 2017;153:e47-8 \\ $0022-5223 / \$ 36.00$ \\ Copyright (c) 2016 by The American Association for Thoracic Surgery \\ http://dx.doi.org/10.1016/j.jtcvs.2016.11.012
}

The case report by Abadeer and colleagues ${ }^{1}$ in this issue of the Journal is a rare case of rat bite fever resulting in endocarditis. It is unique in having a rare combination of infected ventricular septal defect (VSD) patch, with endocarditis involving the aortic valve, tricuspid valve, and left ventricular outflow tract resulting in a sinus of Valsalva fistula into the right ventricle. Surgical management of this rare entity required extensive debridement and reconstruction of the crux of the heart including the left ventricular outflow tract.

Rat bite fever is rare, described as early as 1899 by Miyake and outlined in great detail in the case report by Blake in $1916 .^{2}$ There have been 22 reported cases with endocarditis since 1915 described by Fenn and colleagues ${ }^{3}$ in their case report and review in 2014, with a high fatality rate. Endocarditis typically affects diseased valves, and involvement of the aortic, mitral, and tricuspid valves has been described. ${ }^{3}$ Although more common in adults, cases have been reported in children.,

Endocarditis is uncommon in unrepaired VSDs (1.7-2.7/ 1000 patient years) or pathologic valves $(27.1 / 10,000$ patient year for aortic stenosis and 14.5/10,000 patient years for pulmonary stenosis) ${ }^{6,7}$ and even rarer after VSD closure with a reported cumulative incidence of $4 \%$ at 40 years after isolated VSD closure. ${ }^{8}$ Several case reports describe aorto-cardiac fistula. ${ }^{9-14}$ Endocarditis of a sinus of Valsalva fistula necessitates extensive debridement and reconstruction because of the involvement of multiple chambers and valves, and associated mortality is higher. $^{15,16}$

A high index of suspicion is required, as is appropriate testing for identification of the causative organism, because high-dose penicillin therapy is essential for treatment of rat bite fever. Much of the mortality in the earlier series could be attributed to inadequate dosage or inappropriate antibiotic choice. ${ }^{3}$ Repair ideally should be performed after completion of antibiotics and repeat cultures prove negative; however, altered hemodynamics may require earlier intervention. Although appropriate

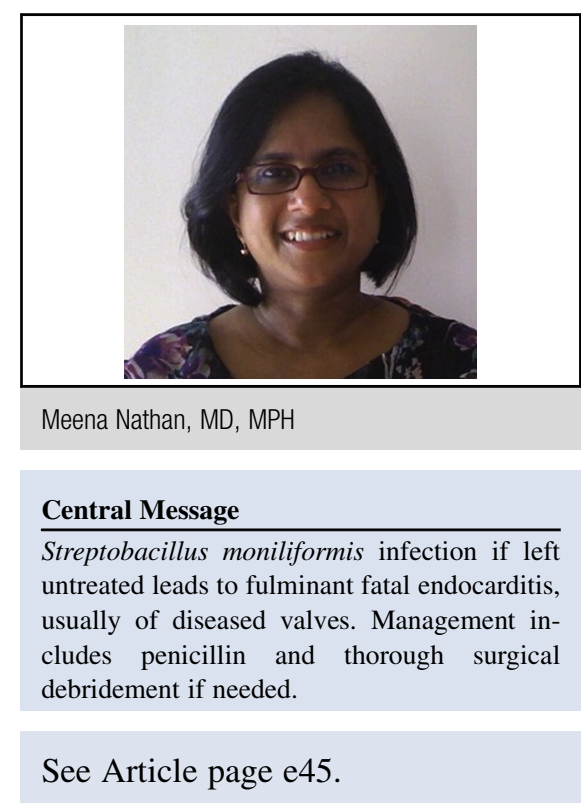

imaging (echocardiography, cardiac magnetic resonance, or computed tomography) guide surgical planning, the ultimate decision on type of repair can be determined only on intraoperative inspection. Aggressive debridement of all infected tissue is key, followed by reconstruction/ replacement of the defects resulting from such debridement preferably with biologic material. However, the choice of prosthesis for valve replacement should be based on patient and technical factors. ${ }^{17,18}$ In this case report, Abadeer and colleagues ${ }^{1}$ illustrate the extent of the defect in the crux of the heart after meticulous debridement of all endocarditic tissue. They chose to use a mechanical prosthesis for aortic valve replacement and used bovine pericardial patch for reconstruction of left ventricular outflow tract and tricuspid valve, and opted for a bioprosthetic pulmonary valve replacement to minimize the hemodynamic burden of a transannular patch. Decision making on the type of repair and type of prosthesis was based appropriately on intraoperative findings and patient's age.

Thus, a high degree of suspicion is necessary for early diagnosis, management, and prevention of complications in rat bite fever (Figure 1). If endocarditis is present, management should be tailored depending on the extent of endocarditic involvement, with the choice of repair/ replacement techniques based on patient and anatomic criteria. 


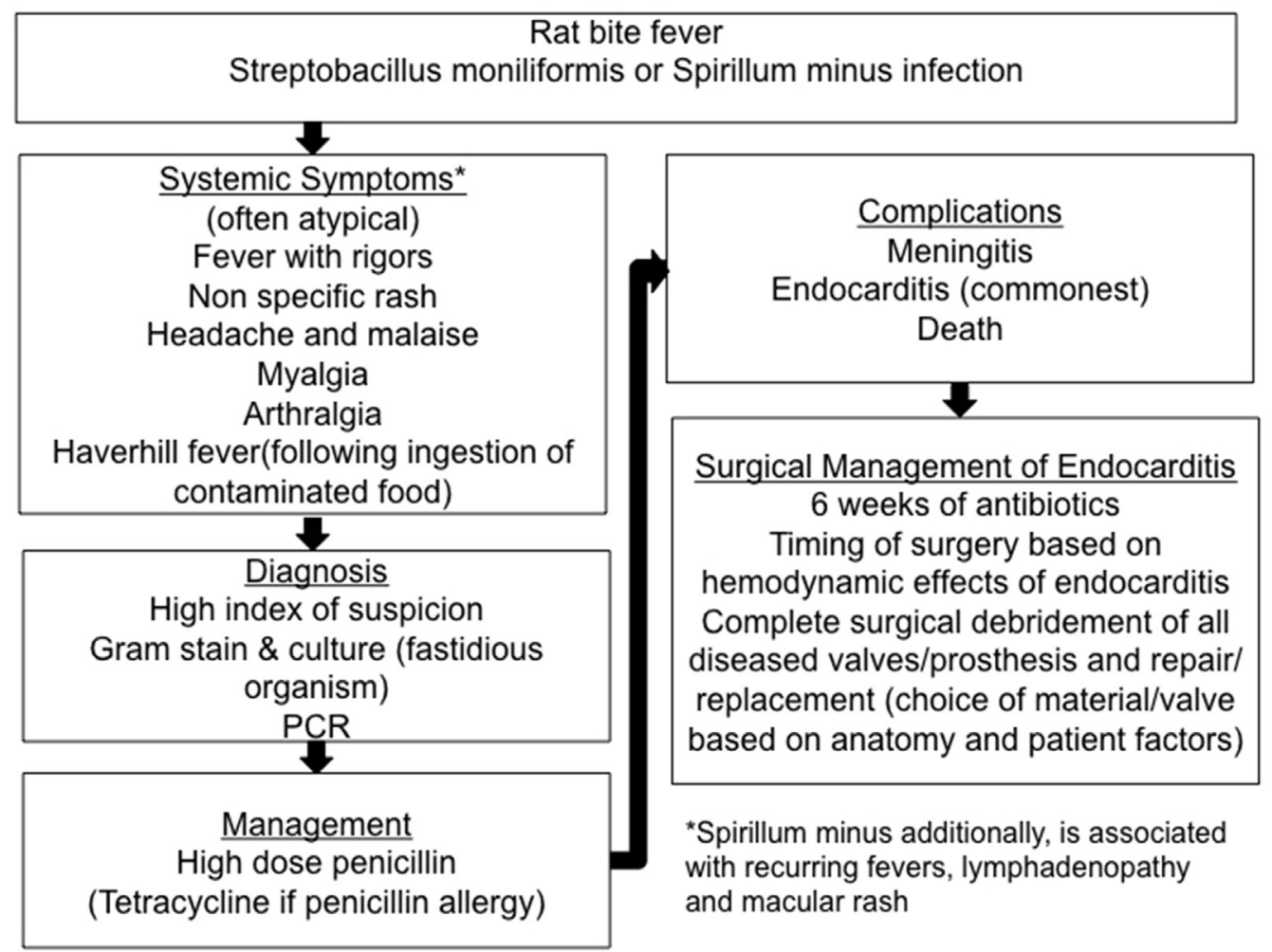

FIGURE 1. Diagnosis and management of rat bite fever and associated endocarditic complications. $P C R$, Polymerase chain reaction.

\section{References}

1. Abadeer MN, Kouretas PC, Woods RK. Rat bite fever-complex triple valve surgery for endocarditis and sinus of Valsalva fistula. J Thorac Cardiovasc Surg. 2017;153:e45-6.

2. Blake FG. The etiology of rat-bite fever. J Exp Med. 1916;23:39-60.

3. Fenn DW, Ramoutar A, Jacob G, Bin Xiao H. An unusual tale of rat-bite fever endocarditis. BMJ Case Rep. 2014;1-5.

4. Blattner RJ. Rat-bite fever. J Pediatr. 1965;67:884-6.

5. Sens MA, Brown EW, Wilson LR, Crocker TP. Fatal Streptobacillus moniliformis infection in a two-month-old infant. Am J Clin Pathol. 1989;91: 612-6.

6. Berglund E, Johansson B, Dellborg M, Sörensson P, Christersson C, Nielsen NE, et al. High incidence of infective endocarditis in adults with congenital ventricular septal defect. Heart. July 21, 2016 [Epub ahead of print].

7. Gersony WM, Hayes CJ, Driscoll DJ, Keane JF, Kidd L, O'Fallon WM, et al. Bacterial endocarditis in patients with aortic stenosis, pulmonary stenosis, or ventricular septal defect. Circulation. 1993;87(2 Suppl):I121-6.

8. Menting ME, Cuypers JA, Opić P, Utens EM, Witsenburg M, van den Bosch AE, et al. The unnatural history of the ventricular septal defect: outcome up to 40 years after surgical closure. J Am Coll Cardiol. 2015;65:1941-51.

9. Zamor N, Phoon C, Malhotra S, Ngai J. Endocarditic sinus of Valsalva fistulae to right ventricular outflow tract in adult ventricular septal defects. J Clin Anesth. 2015;27:347-52.

10. Anguera I, Quaglio G, Miró JM, Paré C, Azqueta M, Marco F, et al. Aortocardiac fistulas complicating infective endocarditis. Am J Cardiol. 2001;87:652-4.
11. John ES, Boyer J, Ledzian B, Steward H, Moro R, Bittner HB. A rare case of sinus of Valsalva-right atrial fistula secondary to an abscess perforation from underlying aortic valve endocarditis. J Cardiothorac Surg. 2014;9:124.

12. Anguera I, Miro JM, Vilacosta I, Almirante B, Anguita M, Muñoz P, et al; Aorto-cavitary Fistula in Endocarditis Working Group. Aorto-cavitary fistulous tract formation in infective endocarditis: clinical and echocardiographic features of 76 cases and risk factors for mortality. Eur Heart J. 2005;26:288-97.

13. Anguera I, Miro JM, Evangelista A, Cabell CH, San Roman JA, Vilacosta I, et al; Aorto-Cavitary Fistula in Endocarditis Working Group. Periannular complications in infective endocarditis involving native aortic valves. Am J Cardiol. 2006;98:1254-60.

14. Graupner C, Vilacosta I, SanRomán J, Ronderos R, Sarriá C, Fernández C, et al. Periannular extension of infective endocarditis. J Am Coll Cardiol. 2002;39: 1204-11.

15. Ott DA. Aneurysm of the sinus of Valsalva. Semin Thorac Cardiovasc Surg Pediatr Card Surg Annu. 2006:165-76.

16. Takach TJ, Reul GJ, Duncan JM, Cooley DA, Livesay JJ, Ott DA, et al. Sinus of Valsalva aneurysm or fistula: management and outcome. Ann Thorac Surg. 1999; 68:1573-7.

17. Neely RC, Leacche M, Shah J, Byrne JG. Current readings: status of surgical treatment for endocarditis. Semin Thorac Cardiovasc Surg. 2014;26:53-66.

18. Kim JB, Ejiofor JI, Yammine M, Camuso JM, Walsh CW, Ando M, et al. Are homografts superior to conventional prosthetic valves in the setting of infective endocarditis involving the aortic valve? J Thorac Cardiovasc Surg. 2016;151: 1239-46. 